\title{
WELCOME TO THE NEW JOURNAL SCIENTIA INSULARUM / ISLANDS SCIENCE
}

\author{
José Carlos Hernández*, Lea de Nascimento** \\ Carlos Sangil* \& José María Fernández-Palacios**
}

As you will notice along this first issue, a new scientific journal entitled Scientia Insularum/Islands Science has been born. The birth of a scientific journal is not a frequent event and this is the reason why we would like to share such a nice moment with you. The four editors-in-chief authoring this welcome text have bet hard for launching a regional journal, with Macaronesia -the sum of the NE Atlantic volcanic archipelagos, comprising Azores, Madeira, Selvagens, The Canaries and Cape Verde - as its natural Lebensraum, but not restricted to Macaronesia, thus welcoming manuscripts from other islands worldwide.

Our main intention is converting Scientia Insularum in an open access and free of charge journal, focused on island research, centred both in terrestrial and marine biological disciplines (such as Biogeography, Ecology, Evolution, Palaeontology, Paleoecology, Conservation, etc.), but also open to non-biological sciences with importance in islands, such as Volcanology, Hydrogeology, Geomorphology, Oceanography or Climatology, among others.

The journal is launched by La Laguna University Press (Servicio de Publicaciones de la Universidad de La Laguna), and will be only published on-line [https:// www.ull.es/revistas/index.php/scientia-insularum/index], in English or Spanish. The idea is to attract the research results of young scientists at the very beginning of their careers, such as Master degree or PhD students, complementing this approach with manuscripts sent by consolidated fellows, for increasing the impact factor and thus the attractiveness of the journal to the academic community. Obviously as newly born, Scientia Insularum still lacks impact factor, but the editorial board will work hard for obtaining it as soon as possible.

Journal Assistant Editors include ten qualified colleagues from the Universidad de La Laguna embracing several research fields, whereas the composition of the journal Scientific Board is exceptional, with more than 50 young scholars belonging to Universities and Research Centres based mainly in the Macaronesian archipelagos.

For this first volume, entitled "Importance of Islands in Natural Science" we have received and selected eight contributions that are mainly focus on the human impacts on the marine environments surrounding the Canary Islands but also on the home range of delphinids around Madeira and Azores, and a preliminary checklist 
of the interesting terrestrial biota of the Chinijo Arquipelago, on the north-eastern side of the Canaries.

This first volume is an invitation to future contributors that will help to highlight the importance of Islands in the Natural Sciences with their works and to create, for the first time, an international journal focus on Island Science that would serve as a participative media for experts and young scientist worldwide.

* Ecología de Comunidades Marinas y Cambio Climático. Departamento de Biología Animal, Edafología y Geología de la Universidad de La Laguna.

** Ecología y Biogeografía Insular. Departamento de Botánica, Ecología y Fisiología Vegetal de la Universidad de La Laguna. 